\title{
SELECTIVITY INDEX BASED ANALYSIS OF BLOCK-WISE RURAL OUT MIGRATION: A CASE STUDY OF EAST CHAMPARAN DISTRICT OF BIHAR, INDIA
}

\author{
Abhay Kumar ${ }^{1}$ and Sandesh Yadav ${ }^{2}$ \\ ${ }^{1}$ Alumnus, Department of Geography, Jamia Millia Islamia, New Delhi, India \\ ${ }^{2}$ Freelance Researcher, New Delhi, India \\ Corresponding author's Email: sandesh_official@yahoo.in
}

\begin{abstract}
Migration is a positive process on one hand and necessary evil on the other. In former case, migrants contribute in the developmental processes of country by working as skilled and non-skilled labourers while in latter case, migration also results in problems like urban sprawl, urban poverty, social conflicts. The present research paper focuses on the rural migrants engaged in workforce of unorganized sector and also answers the question that 'how urban and industrial regions attracting people from rural areas to work and earn more money as compared to their place of origin?' The methodology involves the field survey of two Community Development Blocks namely Motihari and Tetaria in the East Champaran district of Bihar, India. The selectivity index was applied to analyses the religion, caste and education based mobility of rural outmigrants.
\end{abstract}

Key words: Rural outmigration, Unorganized sector, Selectivity index, Workforce.

\section{Introduction}

In today's era of globalization, urbanization and industrialization, all regions irrespective of rural characteristics and urban characteristics are interlinked and interdependent through improved network of communication and transport, hence have resulted in increased flow of information and rapid mobility of migrants. In current scenario, various push and pull factors at the place of origin and place of destination have played major role in determining the migrating patterns of human being (Joseph, 1988). Economic opportunities serve as the major pull factors in making people to migrate from their places of origin (Ranis and Fei, 1961). Migration on the one hand determines the demographic attributes and flow of workforce on the other. An analysis of trends and patterns of migration gives the percentage increase in the 'add-on' number of people which are responsible for demographic changes in country or any part of the country (Davis, 1963). Consequently, place of origin become depopulated and place of destination become overpopulated and consequently, migration results in demographic change.

\section{Objectives of the Study}

- To assess the block-wise rural outmigration in the East Champaran district, Bihar, India

- To analyze the mobility of rural out migrants by applying selectivity index on religion, caste and education in the East Champaran district, Bihar, India. 


\section{Figure 01: Structure of the Research Study}

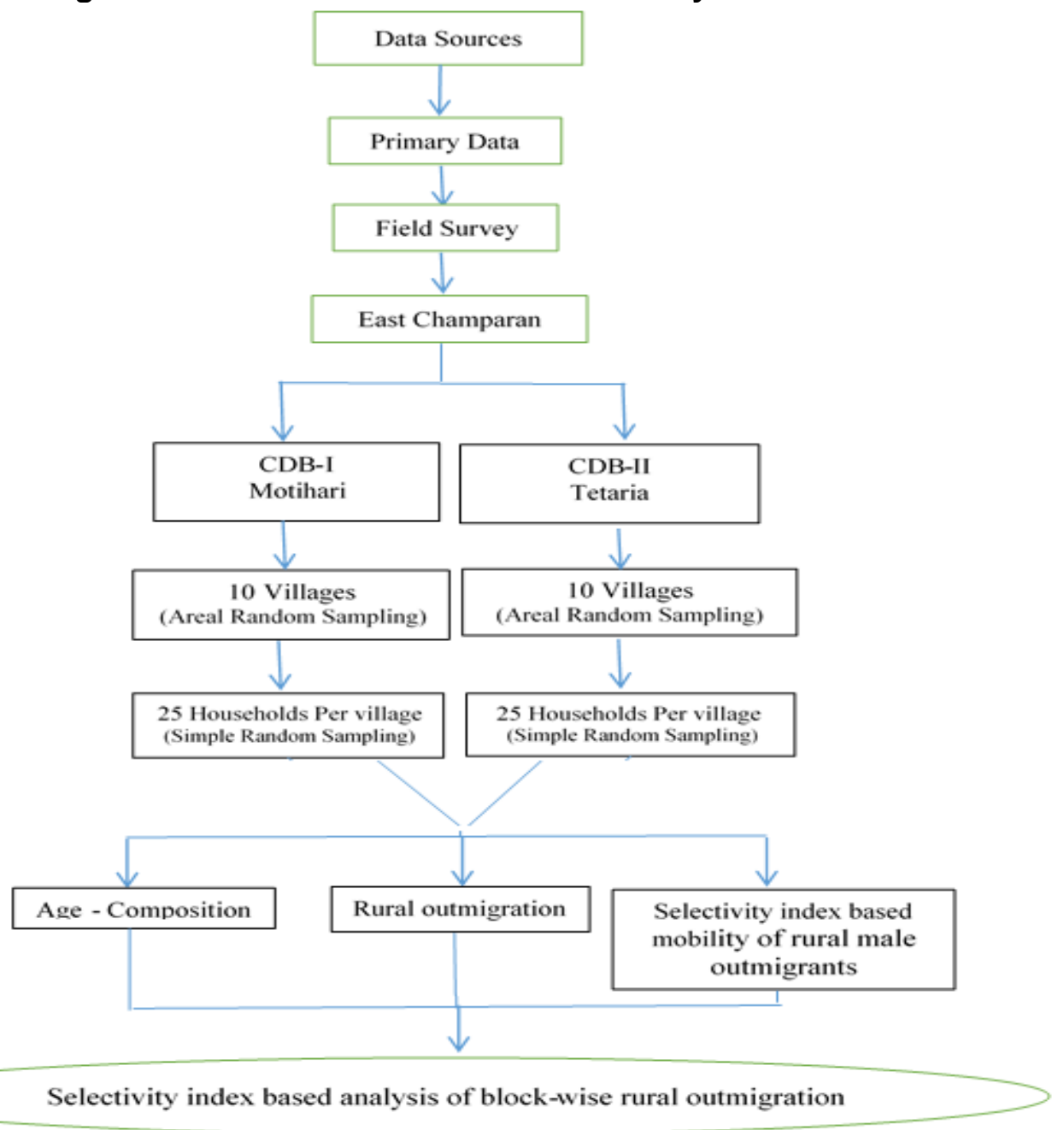

Source: Prepared by the author

\section{Methodology}

Figure 01 shows the structure of the present research study and the various aspects involved in the study.

\section{Data Sources}

The collection of primary data was carried out through comprehensive field survey during the year 2017. The structured questionnaires were used to collect information on demographic and socio-economic attributes of rural out-migrants of two Community Development (CD) blocks namely Motihari (CDB-I) and Tetaria (CDB-II). Figure 01 shows the details of field survey (sampled villages and sampled households) conducted during the year 2017.

\section{Tools of Analysis}

The following formula have been used to calculate the 'selectivity index' for various aspects:

$$
\begin{aligned}
& \text { S.I.= (percentage of outmigrants with specific characteristics to total outmigrants) } \\
& \text { (percentage of persons with these characteristics in the total population of the community) }
\end{aligned} 100
$$


'Selectivity Index' was used to study the movement of migrants, higher values of selectivity index show the active migration while lower values of selectivity index show the inactive migration.

Figure 02: Location map of East Champaran, Bihar, India

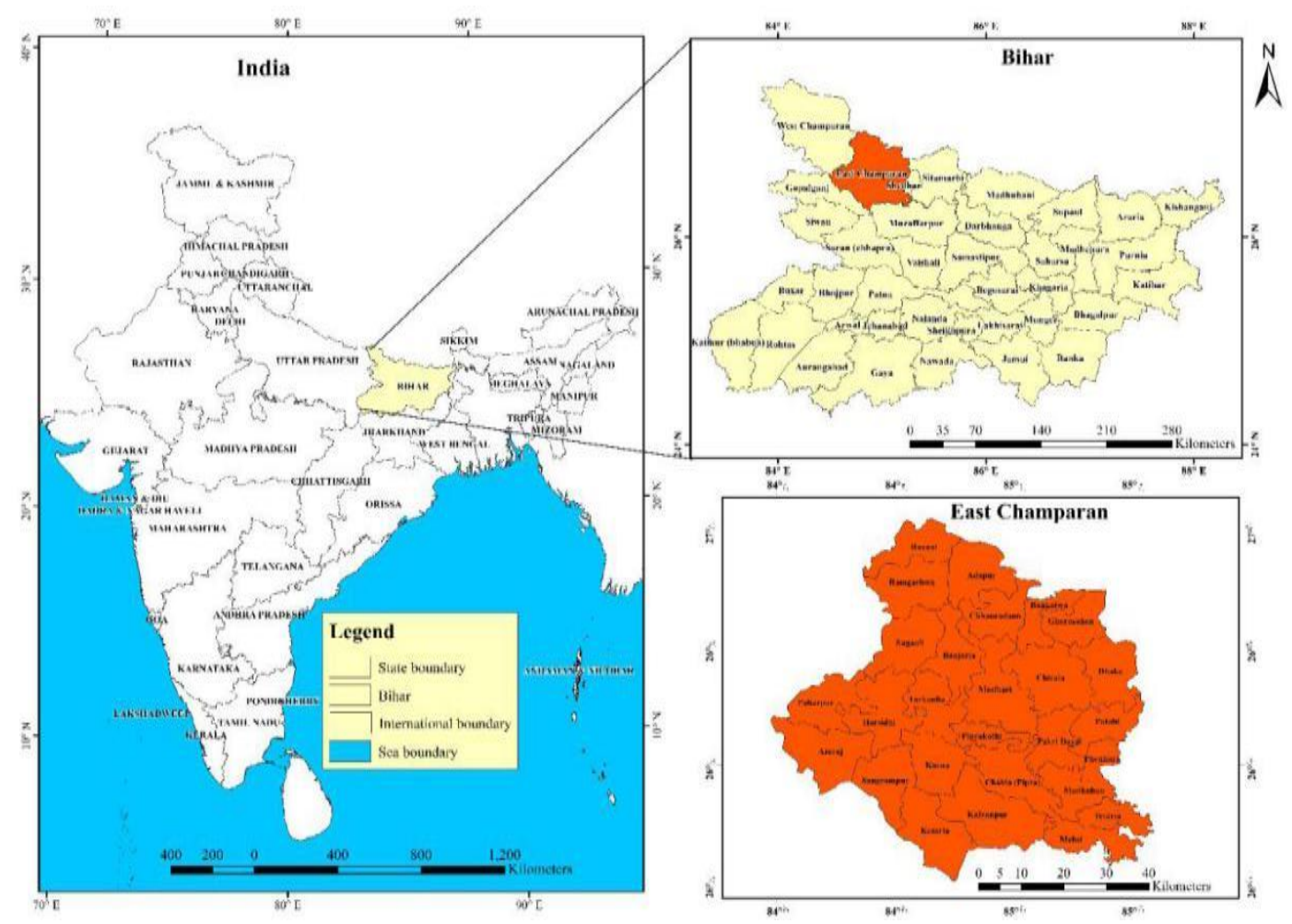

\section{RESULT AND DISCUSSION}

\section{Demographic Attributes of Rural Migrants}

The CDB-I (Motihari) was having 1316 persons (Table 01) out of the total sampled population of 2556. Out of the total population of 1316, number of out-migrants were 322 (24.47 percent) which comprised of 219 males (68.01 percent) and 103 females (31.99 percent). On the other hand, the CDB-II (Tetaria) was having 1240 persons (Table 01) out of the total sampled population of 2556. Out of the total population of 1240 , number of out-migrants were 296 (23.87 percent) which comprised of 202 males (68.24 percent) and 94 females (31.76 percent).

\section{Age Composition of Rural Male Migrants and Rural Male Non-Migrants}

The sampled population consists of villagers of CDB-I (Motihari) and CDB-II (Tetaria). The present research study discusses the age-composition of rural male migrants and male non-migrants and become more specific to male migrants while discussing the broad categories of age groups (Figure 03).

Figure 04 shows that maximum percentage of male migrants belong to age-groups of 20-24 years (27.08 percent), 25-29 years (24.23 percent), 30-34 years (14.49 percent), 35-39 years (9.03 percent), $15-19$ years (7.84 percent) and 40-44 years (7.36 percent). These age-groups constitute major section of migrant population because they are considered as the main working population. Further, the age-groups which seem less active as migrants include $0-4$ years (0.48 percent), $10-14$ years $(2.14$ percent), $45-49$ years (3.33 percent), $50-54$ years ( 1.43 percent) and $60+$ years $(0.48$ percent). 
Table 01: Village-wise Population of Out-migrants and Their Composition in CDB-I (Motihari) and CDB-II (Tetaria), East Champaran, Bihar

\begin{tabular}{|c|c|c|c|c|c|c|c|}
\hline \multirow[t]{2}{*}{ C.D. Blocks } & \multirow[t]{2}{*}{ Villages } & \multicolumn{3}{|c|}{ Sample Population } & \multicolumn{3}{|c|}{ Total Out-Migrants } \\
\hline & & Male & Female & Total & Male & Female & Total \\
\hline \multirow{10}{*}{$\begin{array}{l}\text { CD Block -I } \\
\text { (Motihari) }\end{array}$} & Jhit Kahiya & 93 & 50 & 143 & 21 & 11 & 32 \\
\hline & Lakhaura & 78 & 44 & 122 & 23 & 13 & 36 \\
\hline & Barwa & 80 & 54 & 134 & 33 & 17 & 50 \\
\hline & Haraj Tola Lachhmipur & 86 & 43 & 129 & 21 & 9 & 30 \\
\hline & Chhatauni Ramsingh & 96 & 49 & 145 & 23 & 10 & 33 \\
\hline & Ray Singha & 87 & 47 & 134 & 29 & 14 & 43 \\
\hline & Patparia Moran & 99 & 53 & 152 & 19 & 7 & 26 \\
\hline & Bariyarpur & 73 & 43 & 116 & 17 & 6 & 23 \\
\hline & Bankat & 67 & 43 & 110 & 11 & 5 & 16 \\
\hline & Baswaria & 84 & 47 & 131 & 22 & 11 & 33 \\
\hline Total CD Block-I & & 843 & 473 & 1316 & 219 & 103 & 322 \\
\hline \multirow{10}{*}{$\begin{array}{l}\text { CD Block -II } \\
\text { (Tetaria) }\end{array}$} & Dhobwaliya & 90 & 43 & 133 & 21 & 10 & 31 \\
\hline & Fazilpur & 71 & 41 & 112 & 23 & 10 & 33 \\
\hline & Saraiya & 73 & 49 & 122 & 30 & 14 & 44 \\
\hline & Sonaul & 79 & 49 & 128 & 21 & 8 & 29 \\
\hline & Tajpur & 91 & 39 & 130 & 23 & 10 & 33 \\
\hline & Kadma & 81 & 41 & 122 & 22 & 13 & 35 \\
\hline & Kothia & 93 & 51 & 144 & 15 & 7 & 22 \\
\hline & Pipra & 71 & 40 & 111 & 17 & 6 & 23 \\
\hline & Sobhitapur & 67 & 42 & 109 & 11 & 5 & 16 \\
\hline & Semraha & 84 & 45 & 129 & 19 & 11 & 30 \\
\hline Total CD Block-II & & 800 & 440 & 1240 & 202 & 94 & 296 \\
\hline
\end{tabular}

Source: Field survey, 2017

Figure 03: Structure of Discussion On Demographic Attributes

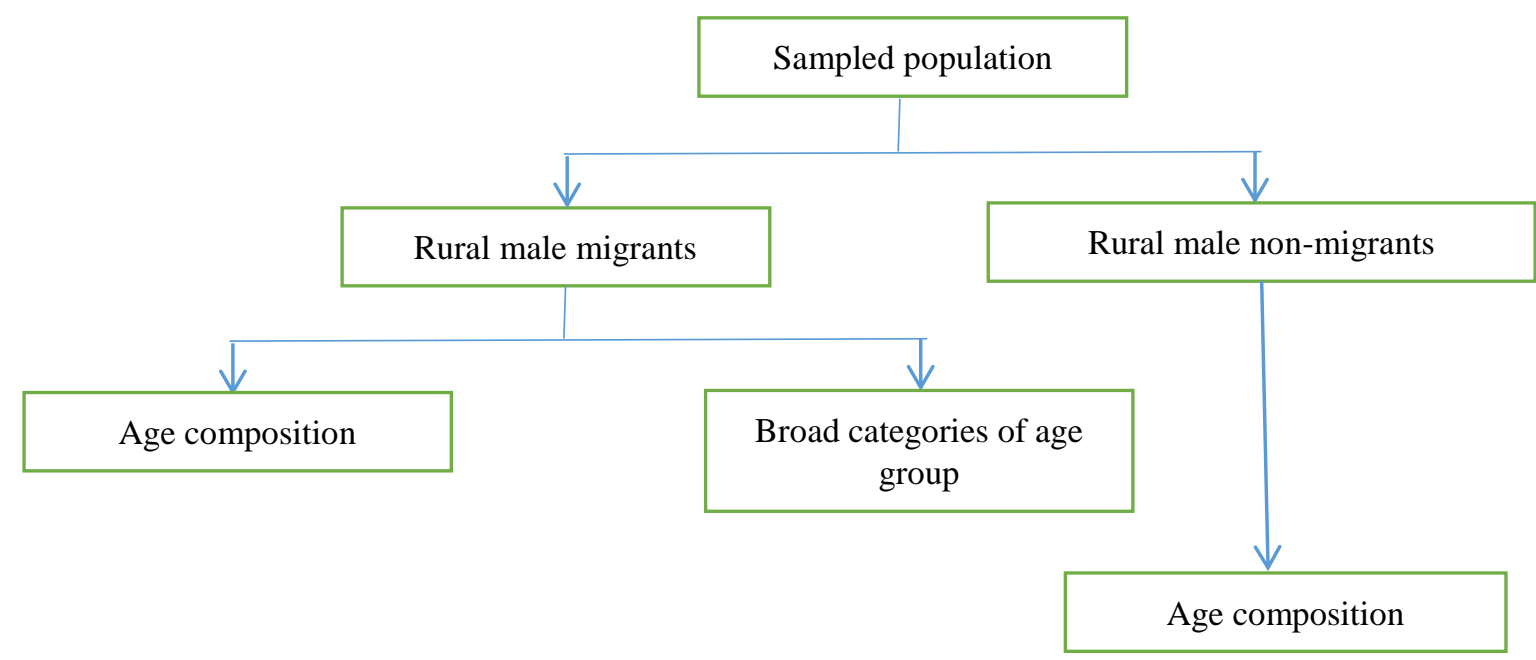


Figure 04 Age-Composition of Male Migrants \& Non-Migrants, East Champaran

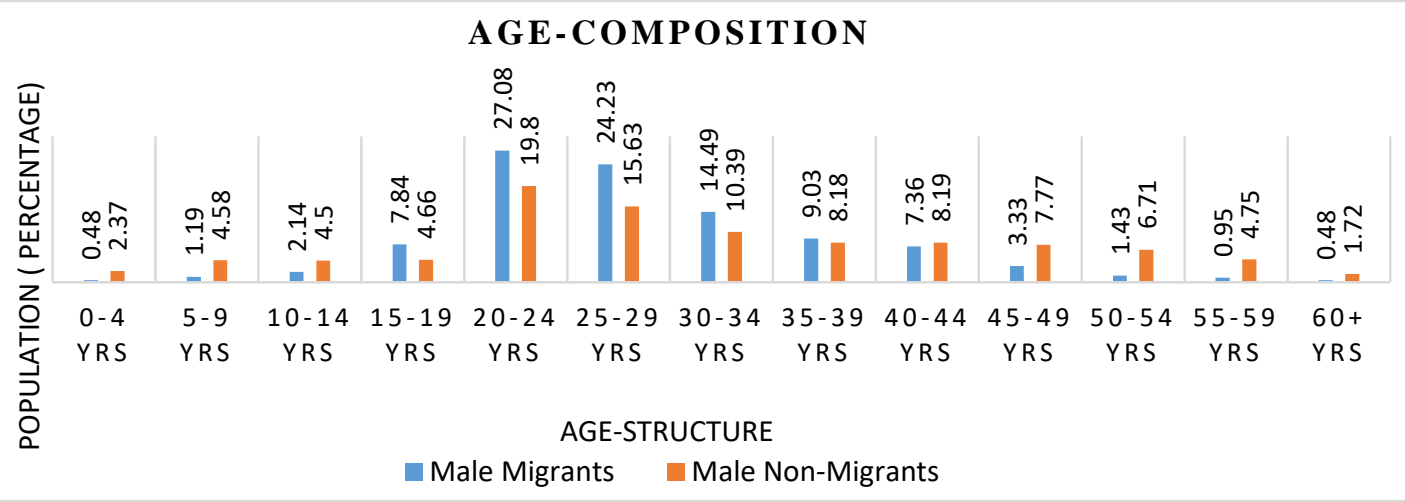

Table 02 shows the data related to broad categories of male out-migrants containing more than one age-groups in the East Champaran. The broad category of children includes age-groups of 0-4 years, 5-9 years and 10-14 years; young migrants are in age-groups of 15-19 years and 20-24 years; middle aged migrants include agegroups of 25-29years, 30-34 years and 35-39 years; upper middle age groups include 40-44 years, 45-49 years, 50-54 years, 55-59 years; while aged migrants include $60+y e a r s$. The highest percentage of male migrants belong to middle age groups (47.74 percent) followed by young migrants (35.92 percent) while the least number of migrants are of children (3.80 percent) and aged migrants ( 0.48 percent).

Table 02: Broad Age-Group Categories of Rural Male Migrants, East Champaran

\begin{tabular}{|c|c|c|c|}
\hline Age-Group & $\begin{array}{c}\text { Broad Categories of } \\
\text { Migrants }\end{array}$ & Male Migrants & Percentage \\
\hline $0-4$ & \multirow{3}{*}{ Children } & \multirow{3}{*}{16} & \multirow{3}{*}{3.80} \\
\hline $5-9$ & & & \\
\hline $10-14$ & & & \\
\hline $15-19$ & \multirow[t]{2}{*}{ Young Migrants } & \multirow[t]{2}{*}{147} & \multirow[t]{2}{*}{35.92} \\
\hline $20-24$ & & & \\
\hline $25-29$ & \multirow[t]{3}{*}{ Middle Age Migrants } & \multirow{3}{*}{201} & \multirow{3}{*}{47.74} \\
\hline $30-34$ & & & \\
\hline $35-39$ & & & \\
\hline $40-44$ & \multirow{4}{*}{ Upper Middle Age Migrants } & \multirow{4}{*}{55} & \multirow{4}{*}{13.06} \\
\hline $45-49$ & & & \\
\hline $50-54$ & & & \\
\hline $55-59$ & & & \\
\hline $60+$ & Aged Migrants & 2 & 0.48 \\
\hline Total & & 421 & 100.00 \\
\hline
\end{tabular}

Source: Field survey, 2017

The younger section (15-19 yrs., 20-24 yrs., 25-29 yrs., 30-34 yrs.) of working population shows high migration tendencies to earn more money (Kumar, Sarvottam, 2005). The societal pressure, family responsibilities and increased expenditure of newly married couples collectively acts as push factors (Kothari, D.K., 1980). The tendency of migration declines among the aged people (40-44 yrs., 45-49 yrs., 50-54 yrs., 55-59 yrs.) due to retarded health conditions and decreased energy level as compared to younger people.

\section{Rural Out Migration}

Here, rural outmigration has been discussed from community development blocks to different states (domestic migration) and other countries (international migration). Now, domestic migration is also discussed in terms of 'type of cities' (Class-I type, class-II 
type etc.) of different States receiving the rural male migrants from CDB-I (Motihari) and CDB-II (Tetaria) of East Champaran district, Bihar (Figure 05).

Figure 05: Aspects of Rural Out Migration Covered

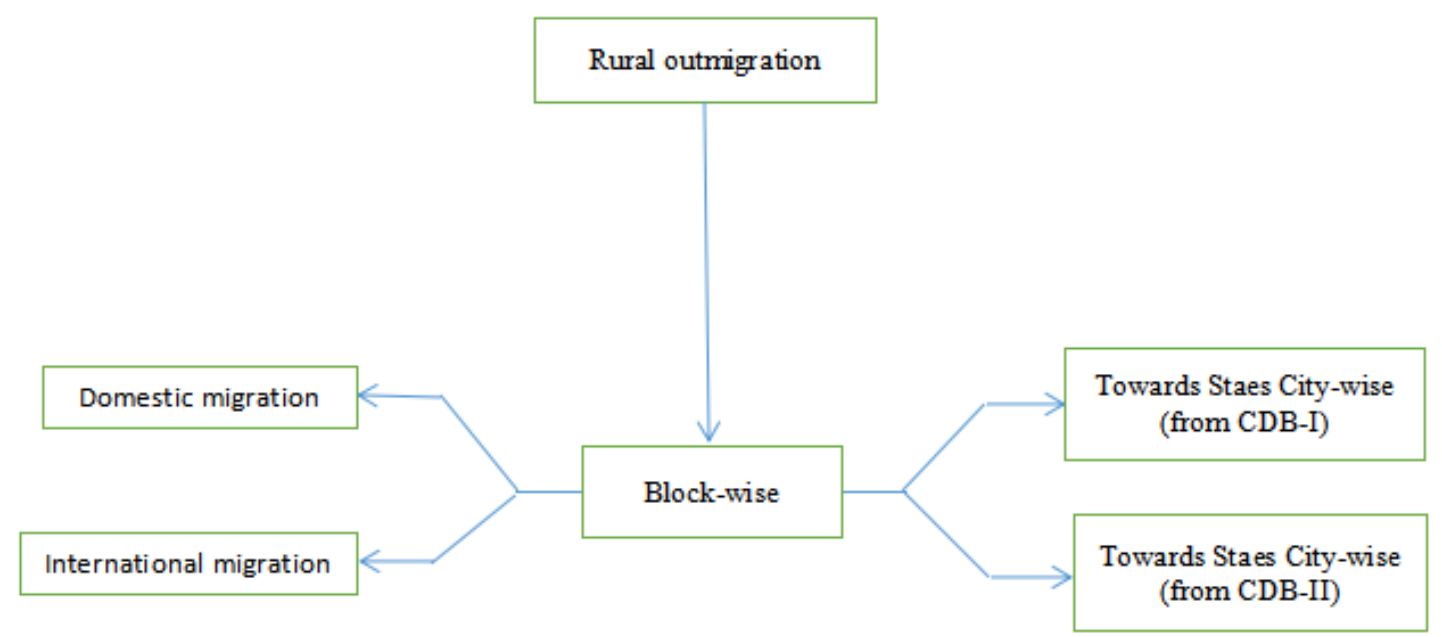

Source: Prepared by the author

Figure 06 shows that out of total 618 out-migrants, 5.18 percent moved within district, 9.06 percent moved within State, 82.85 percent moved within country and 2.91 percent moved abroad. To obtain crystal clear picture of out-migrants and their regional patterns of movement we analyzed the movement of out-migrants at the block level. CDB-I (Motihari) had least percentage of out-migrants moving abroad (3.41 percent) while the majority of out-migrants (81.06 percent) have moved to different states. Apart from these two regional patterns of migration, out-migrants moving within district were only 5.28 percent in comparison to out-migrants moving within state that is 10.25 percent. On the other hand, CDB-II (Tetaria) had least percentage of out-migrants moving abroad (2.36 percent) while the majority of out-migrants (84.80 percent) have moved to different states. Apart from these two regional patterns of migration, outmigrants moving within district were only 5.07 percent in comparison to out-migrants moving within state that is 7.77 percent.

Figure 06: Block-Wise Domestic and International Migration from East Champaran, Bihar

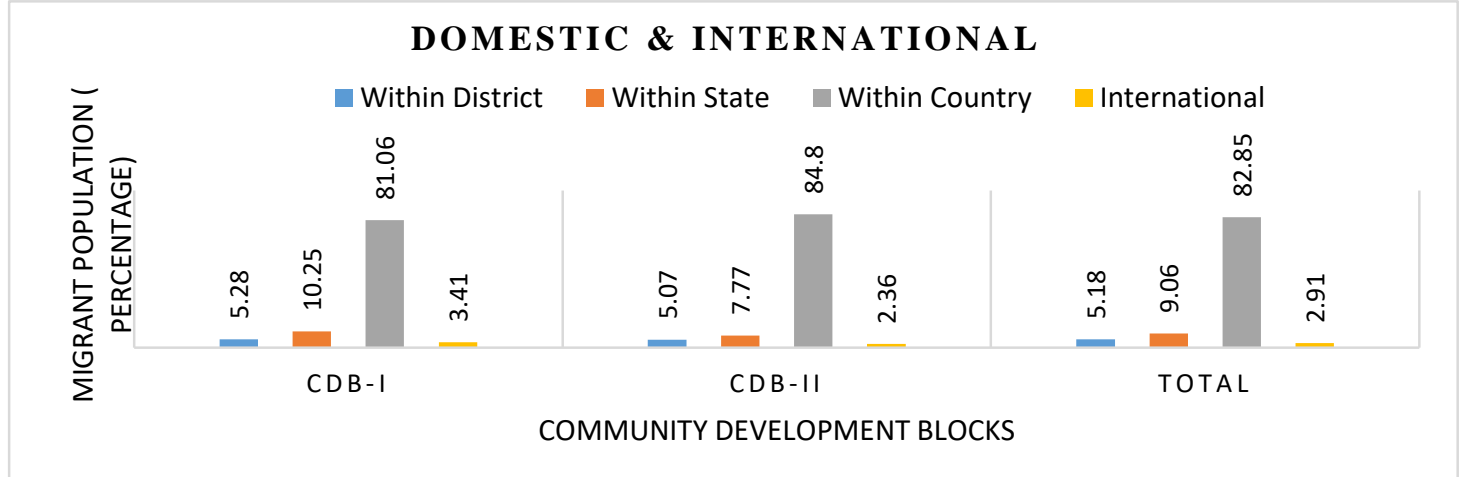

Source: Field survey, 2017

The block-wise analysis of out-migrants to class I cities, class II cities, smaller towns, rural areas show clear picture of out-migrants from CDB I (Motihari) and CDB II (Tetaria). From CDB I (Motihari), (Figure 07) the out-migrants moving 'within district' include nil moved to class I cites, 4.82 percent moved to class II cities, 0.64 percent moved to smaller towns and nil moved to rural areas. Likewise, the out-migrants moving 
'within state' include 6.43 percent towards class I cities, 1.61 percent towards class II cities, 1.29 percent towards smaller towns, 1.29 percent towards rural areas. The movement of out-migrants 'within country' shows that 55.31 percent towards class I cities, 18.33 percent towards class II cities, 8.04 percent towards smaller towns and 2.25 percent towards rural areas. Overall scenario shows 5.47 percent moved 'within district', 10.61 percent moved 'within State' and 83.92 percent moved 'within country'.

Figure 07: Block-Wise Regional Pattern of Rural Out Migration from CDB-I (Motihari), East Champaran, Bihar

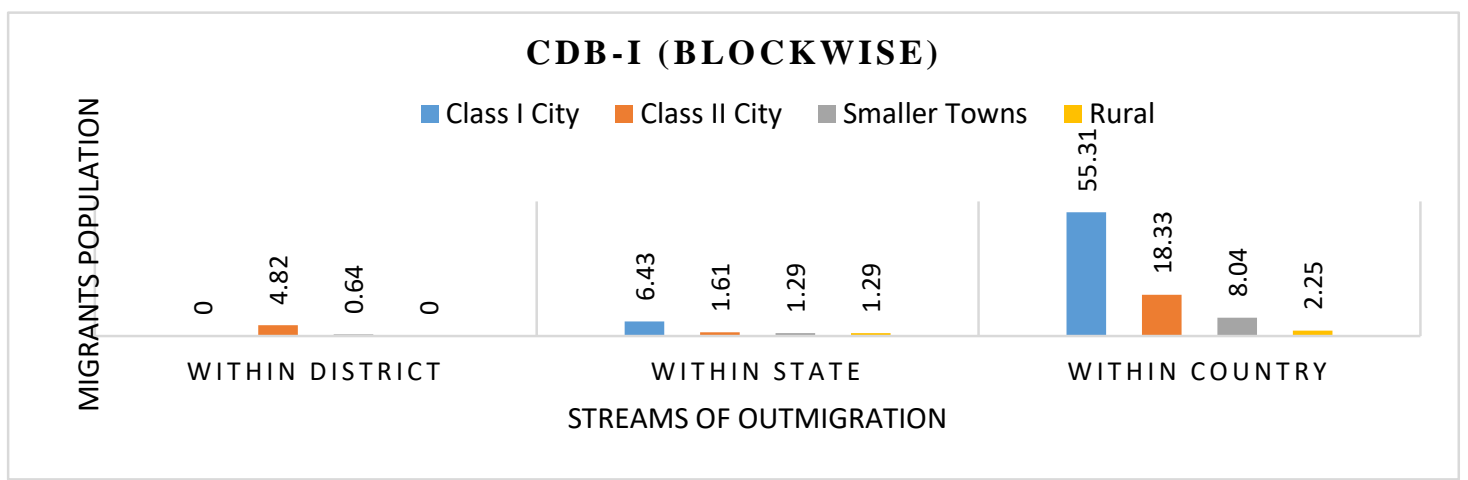

Source: Field survey, 2017

From CDB II (Tetaria), (Figure 08) the out-migrants moving 'within district' include nil moved to class I cities, 4.50 percent moved to class II cities, 0.35 percent moved to smaller towns and 0.35 percent moved to rural areas. Likewise, the out-migrants moving 'within state' include 3.11 percent towards class I cities, 3.11 percent towards class II cities, 1.04 percent towards smaller towns and 0.69 percent towards rural areas. The movement of out-migrants 'within country' shows that 56.40 percent towards class I cities, 19.72 percent towards class II cities, 7.96 percent towards smaller towns and 2.77 percent towards rural areas. Overall scenario shows that 5.19 percent moved 'within district', 7.96 percent moved 'within state' and 86.85 percent moved 'within country'.

Here, it was observed that poor and unskilled rural migrants have tendency to travel short distances in order to find work suitable to them. Consequently, their migration tendency was confined to 'within district' and 'within State' only. Contrary to this, skilled (driver, plumber etc.) and semi-skilled (rickshaw puller, labours, construction worker etc.) rural migrants travel long distances and work throughout the length and breadth of the country.

Figure 08: Block-wise Regional Pattern of Rural Out Migration from CDB-II (Tetaria), East Champaran, Bihar

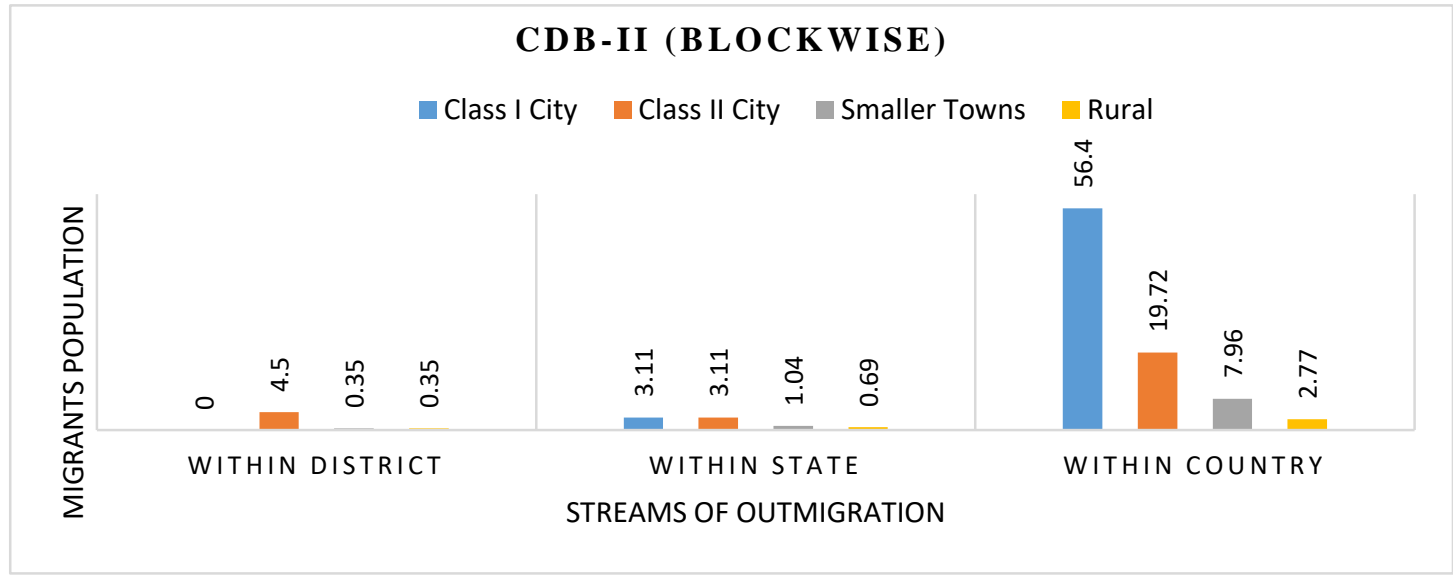

Source: Field survey, 2017 
The scenario of CDB-I shows that 29.12 percent moved towards NCR of Delhi, 24.14 percent moved towards Maharashtra, 17.62 percent moved towards West Bengal, 9.58 percent moved towards Jharkhand, 7.66 percent moved towards Punjab, 4.60 percent moved towards Haryana, 2.30 percent moved towards Uttar Pradesh, 1.15 percent moved towards Gujarat, 1.15 percent moved towards Rajasthan, 1.53 percent moved towards Karnataka and 1.15 percent moved towards others State. The total migration from CDB-I towards class - I city accounts the highest percentage (65.90 percent) followed by the class-II (21.83 percent), smaller towns (9.57 percent) and rural areas (2.68 percent).

\section{Figure 09: City-wise Rural Out Migration to different States from CDB-I} (Motihari), East Champaran, Bihar

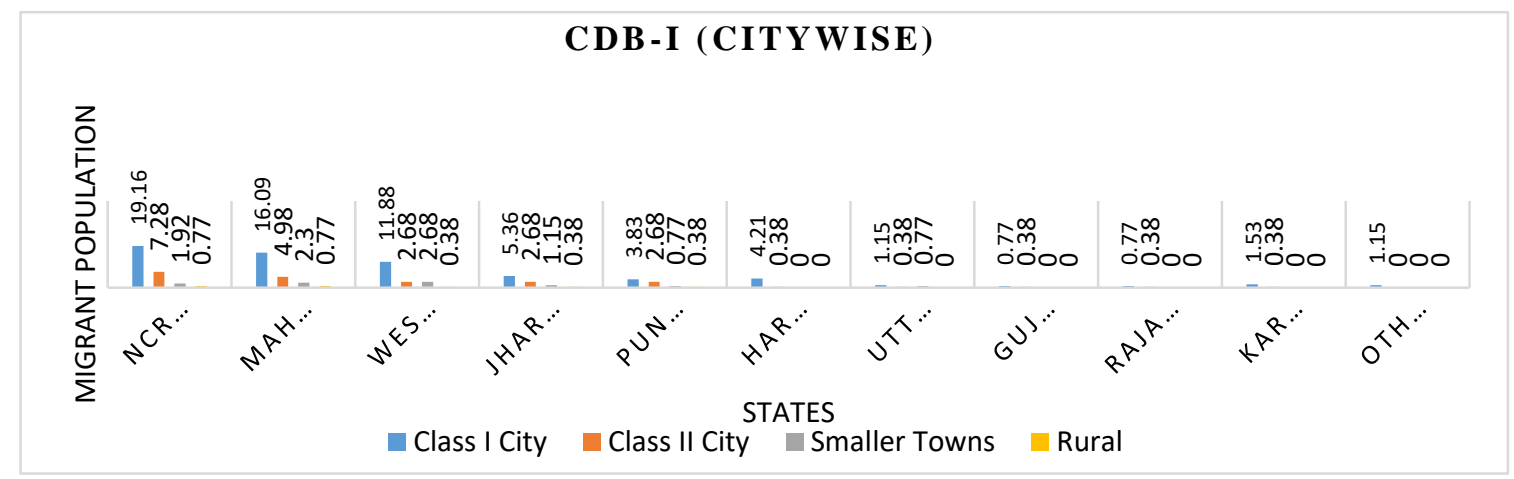

Source: Field survey, 2017

The overall scenario of CDB-Il shows that 21.91 percent moved towards NCR of Delhi, 17.93 percent moved towards Maharashtra, 19.12 percent moved towards West Bengal, 13.15 percent moved towards Jharkhand, 11.16 percent moved towards Punjab, 7.97 percent moved towards Haryana, 1.59 percent moved towards Uttar Pradesh, 1.99 percent moved towards Gujarat, 3.19 percent moved towards Rajasthan, 0.80 percent moved towards Karnataka and 1.20 percent moved towards others state. The total migration from CDB-II towards class - I city accounts the highest percentage (64.94 percent) followed by the class-II (22.70 percent), smaller towns (9.16 percent) and rural areas (3.18 percent).

Figure 10 City-wise Rural Out Migration to different States from CDB-Il (Tetaria), East Champaran, Bihar

\section{CDB-II (CITYWISE)}

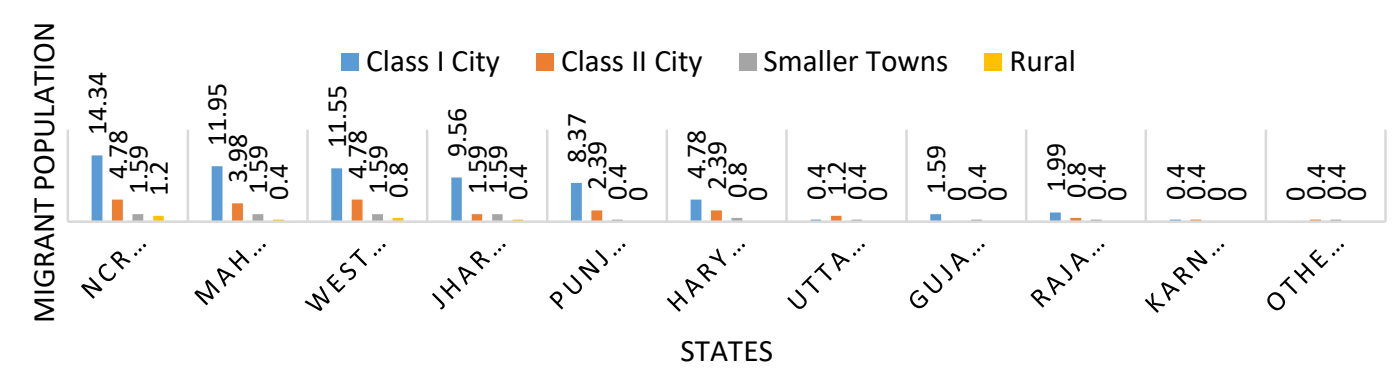

Source: Field survey, 2017

The comparative analysis shows that percentage of rural migrants moving towards Class-I city and smaller towns is higher in CDB-I (Motihar) than CDB-II (Tetaria). On the other hand, percentage of migrants moving towards class-II city and rural areas is higher in CDB-II (Tetaria) than CDB-I (Motihari). 
Now, the demand for 'specific' type of rural migrants at the 'place of destination' determines the degree of migration towards a specific region. For example, Punjab and Haryana are known as agricultural States and demand for unskilled labour is very high during sowing season and harvesting season of crops and thus, cheap, unskilled labour from Bihar migrates towards these two States. Likewise, Mumbai and Delhi pull rural migrants (unskilled) for constructional activities and other developmental processes. Contrary to this, skilled and semi-skilled have better employment opportunities in metropolitan cities and consequently, skilled rural migrants show high degree of migration towards metropolitan cities.

\section{Religion and Caste Based Analysis of Rural Out-Migrants}

The caste-based analysis of out-migrants is based on three broad categories of castes viz. General, Other Backward Classes (OBCs I and OBCs II) and Scheduled Castes (Dalit and Maha Dalit). Further, to give analysis an edge we have also considered Muslim population and their part in outmigration. Table 03 shows the data related to outmigrants based on religion and caste, population of religious community and social category, percentage of out-migrants in their respective religious group and social category and share of religious group and social categories in sample population. Out of 421 male out-migrants, highest percentage of 77.90 percent is shown by Hindu migrants (General class, OBCs, SCs) as compared to 22.09 percent of Muslim migrants.

The scenario of Hindu migrants can be analyzed more specifically in terms of various social categories viz. General class (Brahaman, Bhumihar, Rajput, Kayasth etc.), Other Backward Classes [OBCs-I (Kanu, Kewat etc.) and OBCs-II (Yadav, Kurmi, Kushwaha, Chanau etc.), Scheduled Caste [Dalit (Paswan etc.) and Maha Dalit (Musahar, Majhi, Dom etc.)]. Among Hindu migrants, highest percentage of 17.34 percent is shown by OBCs-I migrants followed by General class migrants (17.10 percent), Maha Dalit (15.91 percent) among SCs migrants, OBCs-II migrants (15.68 percent) and Dalit (11.88 percent) among SCs migrants.

Table 03: Share of Rural Migrants Based on Religion and Caste, East Champaran

\begin{tabular}{|c|c|c|c|c|}
\hline $\begin{array}{c}\text { Social } \\
\text { Categories }\end{array}$ & Out migrants & $\begin{array}{c}\text { Out migrants } \\
\text { ( percent) }\end{array}$ & $\begin{array}{c}\text { Population of social } \\
\text { category } \\
\text { (Total) }\end{array}$ & $\begin{array}{c}\text { Share in Sample } \\
\text { population } \\
\text { ( percent) }\end{array}$ \\
\hline General & 72 & 17.10 & 220 & 13.39 \\
\hline OBCs & 73 & 17.34 & 299 & 18.20 \\
\hline OBCs - I & 66 & 15.68 & 284 & 17.29 \\
\hline OBCs - II & & & & 14.06 \\
\hline SCs & 50 & 11.88 & 231 & 18.99 \\
\hline Dalit & 67 & 15.91 & 312 & 18.08 \\
\hline Maha Dalit & 93 & 22.09 & 297 & 100.00 \\
\hline Muslim & 421 & 100.00 & 1643 & \\
\hline Total & 2017 & \multicolumn{3}{|c}{} \\
\hline
\end{tabular}

Source: Field survey, 2017

Table 03, the share of each category of caste/religion in sample population shows that the percentage of 18.08 percent are from Muslim community as compared to Hindu (81.92 percent). The Hindu migrants show varying share in their respective social categories, percentage of 18.99 percent is shown by Maha Dalit in SCs followed by OBCs-I (18.20 percent), OBCs-II (17.29 percent percent), Dalit (14.06 percent) among SCs and General class (13.39 percent). Table 04 shows that higher selectivity index belongs to General category (127.71), Muslims (122.18), and OBCs I (95.27) showing the higher rate of migration among these two sections of sampled population. Lower selectivity index belongs to OBCs II (90.69), Dalit (84.50) and Maha Dalit (83.78) categories showing the lower rate of migration among these two sections of sampled population. The rural migrants belonging to 'general category' shown high selectivity index (127.71) which justify their high degree of mobility as migrants. First reason 
behind this was the better education which make people of general category more aware and eligible for better job opportunities at the place of destination. Secondly, hesitation due to social prestige associated with their caste prohibit the unskilled and semi-skilled rural people to work or get engaged in petty jobs at the place of origin.

The selectivity index of Muslims is also high (122.18) but comparatively low to rural migrants belonging to general category. The migration tendency of Muslims is more or less driven by circumstances. The prevailing poor economic conditions and less job opportunities, poor wages at the place of origin collectively rural Muslim migrants to other places in order to earn more money. If we talk about international migrants, then majority of them belonged to the category of 'rural Muslim migrants' migrating towards the Gulf countries.

The percentage of OBCs rural migrants [OBC-I (18.20), OBC-II (17.29)] is high but selectivity index [OBCs-I (95.27), OBCs -II (90.69)] is low. The higher percentage is due to the large number of migrants in OBCs category while the low selectivity index can be attributed to the fact that proportion of population of OBCs is high. Previously, the migration among the rural migrants belonging to Other backward classes (OBCs) took place due to the advancement in the tools, techniques and technology made the traditional workers (craftsmen, artisans etc.) to starve and migrate to other places in order to find alternate means of livelihood. Currently, the category of OBCs migrants comprises of marginal farmers and laborers which either migrate or get engaged in primary activities (selling of milk, farm labourers, shopkeepers etc.). The migration of scheduled castes (SCs) is characterized by two important factors viz. (i) poverty oriented (ii) feeling of 'social alienation'. Former push rural migrants of this category to survive and latter, push them to migrate in order to live life of dignity and societal acceptance.

Table 04: Selectivity Index (Religion and Caste Based) of The Rural Migrants, East Champaran, Bihar

\begin{tabular}{|c|c|c|c|c|}
\hline Social Categories & $\begin{array}{c}\text { Out } \\
\text { migrants }\end{array}$ & $\begin{array}{c}\text { Percentage } \\
\text { among Out } \\
\text { migrants }\end{array}$ & $\begin{array}{c}\text { Percentage } \\
\text { Share in Sample } \\
\text { Population }\end{array}$ & Selectivity Index \\
\hline General & 72 & 17.10 & 13.39 & 127.71 \\
\hline OBCs & & & & 95.27 \\
\hline OBCs - I & 73 & 17.34 & 18.20 & 90.69 \\
\hline OBCs - II & 66 & 15.68 & 17.29 & 84.50 \\
\hline SCs & & & & 83.78 \\
\hline Dalit & 50 & 11.88 & 14.06 & 122.18 \\
\hline Maha Dalit & 67 & 15.91 & 18.99 & 100.00 \\
\hline Muslims & 93 & 22.09 & 18.08 & \\
\hline Total & 421 & 100.00 & 100.00 & \\
\hline
\end{tabular}

Source: Field survey, 2017

\section{Education of Rural Out Migrants}

Table 05 shows the educational status in two prominent blocks of East Champaran viz. CDB-I (Motihari) and CDB-II (Tetaria). In CDB-I (Motihari), the highest percentage of 27.85 percent is shown by migrants with 'middle level' educational status followed by migrants with 'primary level' (26.03 percent), migrants with 'secondary level' (14.61 percent), illiterate migrants (10.96 percent), migrants with 'senior secondary level (10.05 percent)', migrants with 'above senior secondary level' (5.48 percent), migrants with 'graduation' (3.65 percent) and migrants with 'post-graduation level' (1.37 percent). On the other hand, In CDB-II (Tetaria), the highest percentage of 31.19 percent is shown by migrants with 'primary level' followed by migrants with 'middle level' (23.76 percent), illiterate migrants (17.82 percent), migrants with 'secondary level' (9.90 percent) migrants with 'senior secondary level (9.90 percent percent)', migrants with 
'above senior secondary level' (3.96 percent), migrants with 'graduation' (1.98 percent) and migrants with 'post-graduation level' (1.49 percent).

Table 05: Percentage of Rural Migrants Based on Educational Background, East Champaran, Bihar

\begin{tabular}{|l|c|c|c|c|}
\hline \multirow{2}{*}{ Educational Status } & \multicolumn{4}{|c|}{ Percentage of Out migrants } \\
\cline { 2 - 5 } & \multicolumn{3}{|c|}{ CDB-I (Motihari) } & \multicolumn{2}{c|}{ CDB-II (Tetaria) } \\
\cline { 2 - 5 } & Number & Percent & Number & Percent \\
\hline Illiterate & 24 & 10.96 & 36 & 17.82 \\
\hline Primary & 57 & 26.03 & 63 & 31.19 \\
\hline Middle & 61 & 27.85 & 48 & 23.76 \\
\hline Secondary & 32 & 14.61 & 20 & 9.90 \\
\hline Senior Secondary & 22 & 10.05 & 20 & 9.90 \\
\hline Above Senior Secondary & 12 & 5.48 & 8 & 3.96 \\
\hline Graduation & 8 & 3.65 & 4 & 1.98 \\
\hline Post-Graduation & 3 & 1.37 & 3 & 1.49 \\
\hline Total & 219 & 100.00 & 202 & 100.00 \\
\hline
\end{tabular}

Source: Field survey, 2017

The selectivity index (Table 06) shows that illiterates (68.48) and educated up to primary level (99.82) are less among migrants. In other words, illiterate and primary level educated migrants are bound by their literacy level to work as labourers. On the other hand, out-migrants attaining education up to secondary level (106.01), senior secondary level (109.07) and above senior secondary level (110.21) showed higher selectivity index which suggests that out-migrants are active in migration. Lastly, the out-migrants with highest selectivity index are graduates (190.00) and post-graduates (198.61) with high degree of migration. This clearly indicates that higher the selectivity index value, higher the rate of mobility.

Table 06: Selectivity Index (Education) of Rural Out Migrants, East Champaran

\begin{tabular}{|l|c|c|c|c|}
\hline \multicolumn{1}{|c|}{ Educational Status } & $\begin{array}{c}\text { Out } \\
\text { migrants }\end{array}$ & $\begin{array}{c}\text { Percentage } \\
\text { among Out } \\
\text { migrants }\end{array}$ & $\begin{array}{c}\text { Percentage } \\
\text { among total } \\
\text { Community } \\
\text { Population }\end{array}$ & $\begin{array}{c}\text { Selectivity } \\
\text { Index }\end{array}$ \\
\hline Illiterate & 60 & 14.25 & 20.81 & 68.48 \\
\hline Primary & 120 & 28.50 & 28.55 & 99.82 \\
\hline Middle & 109 & 25.89 & 23.31 & 111.07 \\
\hline Secondary & 52 & 12.35 & 11.65 & 106.01 \\
\hline Senior Secondary & 42 & 9.98 & 9.15 & 109.07 \\
\hline $\begin{array}{l}\text { Above Senior } \\
\text { Secondary }\end{array}$ & 20 & 4.75 & 4.31 & 110.21 \\
\hline Graduation & 12 & 2.85 & 1.50 & 190.00 \\
\hline Post-Graduation & 6 & 1.43 & 0.72 & 198.61 \\
\hline \multicolumn{1}{|c|}{ Total } & 421 & 100.00 & 100.00 & 100.00 \\
\hline
\end{tabular}

Source: Field survey, 2017

Table 06 shows that selectivity index increases for the migrants belonging to education level of senior secondary (109.07), above senior secondary (110.21), graduation (190.00) and post-graduation (198.61) and this justify the fact that educated migrants have high degree of mobility. Also, educated migrants are more aware about the job opportunities, wages, programs and policies. The educated migrant possesses high level skills which make them eligible for good job opportunities and consequently, their wages/payments (salary) are much higher as compared to unskilled migrants. The higher wages of educated and skilled migrants result in higher remittances which in turn strengthens the local economy. In other words, lack of job opportunities as per the skills pushes the educated migrants towards metropolitan cities. The other aspect is that 
migrants after completing school/college education migrate in order to pursue higher education.

\section{Conclusion}

Though the improper employment opportunities, poor wages and poverty are push factors for one and all rural migrants irrespective of religion, caste and education. The point of consideration over here is that migration need to be checked at the place of origin by providing considerable assistance (both monetary and non-monetary) to landless villagers so that they begin their 'start-up' or small scale industry. Moreover, government need to give due consideration on developing the 'magnet towns' so that migrants find suitable employment opportunities in their neighboring areas. The idea behind the magnet towns is to prevent the metropolitan cities or large urban centers to go beyond their carrying capacity and result in urban sprawl, urban poverty etc.

\section{References}

1. Joseph. K.V. (1988). 'Migration and Economic Development of Kerala', Mittal Publication, Delhi.

2. Ranis, G. and Fei, J.C.M. (1961). 'A Theory of Economic Development', American Economic Review, Vol.51, No. 4, Sept., pp. 533-565.

3. Davis, K. (1963). The Theory of Change and Response in Modern Demographic History. Population Index, 29, 345-366.

4. Kumar, Sarvottam (2005), Rural Male Out migration, Delhi: Vista International Publishing House.

5. Kothari, D.K. (1980). Patterns of Rural-Urban Migration: A case Study of Four Villages in Rajasthan, India, Canberra: Australian National University 